\title{
Intercultural constructions of the New Testament: Epistemological foundations
}

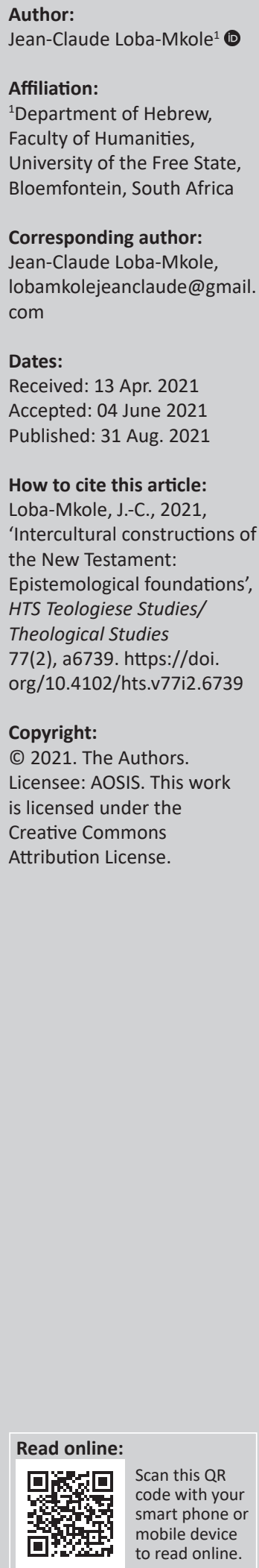

The present study discusses epistemological foundations of intercultural constructions of the New Testament in Africa. Before embarking on this discussion, it documents the history and procedures of this interpretive tool. In Africa, the intercultural method emanates from the paradigm of inculturation coupled with reconstruction. It has already embraced biblical exegesis, translation studies, canonical criticism and ecological hermeneutics.

Contribution: The insights of the article 'Intercultural constructions of the New Testament: Epistemological foundations' pertain firstly to the description of the method of intercultural constructions, taking stock of its emergence, development, procedures, and epistemological foundations in both African and international theological circles. Secondly, the study has specifically established the following epistemological foundations of the intercultural method: interculturality as the cradle of the New Testament corpus, an existential mode, an interpretive paradigm, and interaction with a triple hexagonal dimension. The latter includes a triple pitfall (to avoid), a triple frame of reference, a triple epistemological privilege, a triple epistemological value, a triple ethical value, and a triple cultural position.

Keywords: paradigm; method; construction; narrativity; intercultural; the New Testament.

\section{Introduction}

Intercultural constructions are part of cultural criticism. This method has entered the world of biblical interpretation since the second half of the 20th century. ${ }^{1}$ In the Western world, cultural Bible studies arguably originated in the United States as a part of literary analyses of biblical scenes, themes and stories presented in the traditional arts and modern media. ${ }^{2}$

In Africa, the intercultural method emanates from the paradigm of inculturation coupled with reconstruction. Both are arguably two sides of the same coin, a reality that the concept of intercultural construction captures well (Loba-Mkole 2016). The present study discusses epistemological foundations of intercultural constructions of the New Testament in Africa. Before embarking on this discussion, it documents the history and procedures of this interpretive tool. In Africa, the intercultural method emanates from the paradigm of inculturation coupled with reconstruction. It has already embraced biblical exegesis, translation studies, canonical criticism and ecological hermeneutics.

Questions relating to the history, procedures and epistemological presuppositions are relevant to any scientific discipline (ed. Storey 1996):

[T]raditionally, an academic discipline is defined by three criteria: first, there is the object of study; secondly, there are the basic assumptions which underpin the method (s) of approach to the object of study; and thirdly, there is the history of the discipline itself. (p. 11)

The material object of the intercultural biblical construction under study concerns the New Testament books as recorded at least in one of the Christian Biblical canons. The formal object of this approach is to interpret a biblical text through a sincere dialogue with different cultural frames of reference that inform it, such as original, traditional (ecclesial) and contemporary cultures. The history of intercultural approaches is rooted in both Western and African scholarships.

\footnotetext{
1.See Hoggart (1957), Williams (1958, 1961), Wimbush (1989), Mabee (1991), Moxnes (1998), Brown, Davaney and Tanner (eds. 2001) Exum and Moore (eds. 1998), Ukpong (2002a) and Klingbeil (2005).

2.See Iser (1974:274-294, 1975, 1978), Holland (1968), Bleich (1975), Hall (1980), Easthope (1991) and Grossberg, Nelson and Treichler
} (1993). 
The present study discusses epistemological foundations of intercultural constructions of the New Testament in Africa. However, before embarking on epistemological discussion, it documents the history and procedures of the method concerned. Arguably, the consolidation of a method goes hand in hand with its history, procedures and epistemological fundamentals.

\section{Mapping the intercultural biblical hermeneutics}

In the Western scholarship, intercultural approaches to the New Testament texts are multidimensional, including cultural criticism (Segovia 1995a:68-70, 1995b:303-330; Moore 1992:1-22), history of interpretation ('Auslegungsgeschichte'), reception history ('Receptionsgeschichte'), history of impact ('Wirkungsgeschichte') (Dunn 2003; Luz 2007), historical construction (Schnelle 2005) or a biculturalism (Ehrensperger 2015). In addition, translation studies have also embraced intercultural approach (Bassnett 1998a:72-85, 1998b:57-75; Bassnett \& Lefevere 1990, 1998; Faiq 2004:36).

In Africa, the intercultural method connects with the inculturation. Nevertheless, this interpretive tool incorporates several established methods, such as narrative criticism, historical-critical methods and others. The term biblical inculturation hermeneutics in African contexts is associated with Ukpong (1996). This method continues to spread under various names: intercultural exegesis, intercultural mediation, intercultural criticism, intercultural construction, intercultural narrative or intercultural ecojustice hermeneutics. Thus, the terms inculturation and intercultural can be interchangeable. Still, intercultural approaches are a methodological expansion and an epistemological reconfiguration of the inculturation paradigm. The focus of the inculturation method has been the incarnation of the Gospel into the culture and the evangelisation of the culture. In contrast, the intercultural approach deepens this transformative encounter through a continuous, sincere and constructive dialogue between three frames of reference, involving an original biblical culture, a church culture and a targeted contemporary culture.

Most of its protagonists are African Catholic exegetes. The latter is a significant pillar of the Kinshasa school of thought that goes back to the 1950s (cf. eds. Bujo \& Ilunga 2003, 2006, 2013) but is still ill-represented in Anglophone Africa scholarship. Thus, the terms inculturation and intercultural can be interchangeable. Still, intercultural approaches are a methodological expansion and an epistemological reconfiguration of the inculturation paradigm. Most importantly, the intercultural interpreter recognises and respects the unique and irreplaceable epistemological privileges of each culture involved.

The word culture is understood as a totality of human experience lived in a determined spatial-temporal setting (Loba-Mkole 2011b:6; Pénoukou 1991:45). Culture in its unity and diversity is the determining factor for the naming and shaping of this method. For example, the present intercultural construction is an interpretation that derives from two interpretative paradigms that are relatively popular in Africa, namely inculturation and (re) construction. Considering the literal and metaphorical meaning of the term construction (Deist 2000; Shanor 1988:461-471), what I call 'intercultural construction' uses elements from different cultures to build a new culture (Loba-Mkole 2016:100-119, 2019b:156-180; Schnelle 2005:29). It can apply to sacred or non-sacred texts. An intercultural biblical construction is based on three frames of reference: original biblical cultures, ecclesial cultures and target contemporary cultures (LobaMkole 2005a, b:291-326, 2010:125, 2012:37, 2016:254, 2019a, 2019b:170-174).

The intercultural construction method resembles other contextual methods such as 'Reading With' approach (West 1995, 1999). However, the latter positions itself as a liberation hermeneutics. Nevertheless, West (2014) has also shifted to intercultural hermeneutics of liberation in which intercultural dialogue is a key component (see already De Wit 2004a, b; De Wit 2012). Still, West - like many other proponents of the intercultural approach - does not include a Church culture as a constituent of dialogue. Interestingly, both West and De Wit count amongst the scholars who have applied this method to the Old Testament texts.

I am from the Indrǔ (Ngiti) tribe of the Holy Family Catholic Parish of Gety, founded by the Missionaries of Africa (White Fathers) in 1935 in the Catholic Diocese of Bunia, Ituri Province, DR Congo. I first encountered the concept of inculturation in the 1970s when my Parish started creating awareness about the pastoral directives of the sixth Episcopal Conference of DR Congo, which took place in 1961 and included an emphasis on Small Christian Communities as a form of an 'inculturated' Church. The Council of Vatican II enforced these pastoral directives in 1965, whilst Bimwenyi Kweshi provided theological foundations to them in 1981. Besides, the inculturation paradigm has already embraced biblical exegesis, translation studies, canonical criticism and ecological hermeneutics. The first New Testament in Ndrǔna (Ngiti) language, an apex of inculturation or intercultural exercise amongst the Indrǔ people, was published in 2015.

Some critics could point to the interdisciplinary nature of intercultural construction as its weakness, as Sparks (1997:24) puts it: 'a veritable rag-bag of ideas, methods and concerns ... lumped together under the convenient label of cultural studies'. However, biblical interpretation implies 'the total cultural system of relevant literature and inter-cultural communication' (Deist 2000), as well as an openness to the infinity, a multiform dialogue with the other (Betancourt-Fornet 2011:153; Ndala-Kabemba 2013:62).

In short, intercultural biblical hermeneutics is growing in the West and Africa because of cultural studies or pastoral 
directives. It is interdisciplinary by its very nature, and it is open to carrying on the multifaced, cultural dialogues that religious discourses imply. The following section documents the history and procedures of intercultural constructions of the New Testament in Africa.

\section{History and procedures of intercultural constructions of the New Testament in Africa}

The ultimate origins of intercultural biblical or religious hermeneutics in Africa do not coincide with the Western missionaries' arrival or the emergence of post-colonial inculturation theology. Instead, they relate to the advent of the Word of God through ancestral religions (see BatuafeNgole 2020; Bimwenyi 1981, 1998; Kabasele-Lumbala 1993; Luka 2008, 2010; Ngindu-Mushete 1989; Ngalula-Tshianda 2020). It is the same Gospel or Word of God, which JesusChrist, the incarnated, crucified and risen Son of God, did not come to destroy but to fulfil (cf. Mt 5:17), and through faith in him, all people of different races and tribes are re-established as sons and daughters of God (Gl 3:26.20).

Egypt and Kush (Ethiopia-Sudan) would be amongst the first African territories where the same God, יהוה in Hebrew or Kàgàwà in Ndrŭna (Ngiti) , a Sudanic language of DR Congo (Kutsch 1993), had revealed himself to the descendants of Adam and Eve long before the stories recorded in the Bible (cf. Gn 4:26; 10:1-32, Ex 3:1-22, Luka 2008:5, 2010:21). Linguistic studies indicate that extent Sudanic languages represent the proto-language from which stems the ancient Egyptian language, including the Hebrew divine name יהוה (cf. Obenga 1993:373; Luka 2008:5, 2010:21). Although specific notions of the divine being may differ from one faith community to another (see Han \& Beyers 2017:5-29), God is one (Dt 6:4, Mk 12:29, Gl 3:20). He or she is the same whom the Jews address as Elohim or Yahweh, whilst the Indrǔ (Ngiti) from either Christian or traditional faith refers to him or her as Kàgàwà, which is the only proper name for God.

Any religious discourse is theo-anthropic (Bimwenyi 1981), that is an inter-relational narrative that involves the communication between God and human beings since the creation (Gn 1:1-2.25). In other words, any religious discourse is an intercultural narrative featuring an exchange between divine culture and human cultures. The divine-human interaction is often mediated by individuals such as priests, prophets and kings or by an entire community confessing their faith or performing spiritual rituals and related activities within their cultural framework.

For example, in Ndrǔna (Ngiti) language, the confession of faith like 'Yěsù (Yěsùwa) ní Kàgàwà t'Ídhùnà' (literally Jesus (Yeshuah) is the Son of יהוה, cf. Mk 1:1; 14:62) becomes possible, intelligible, relevant and salvific through a sincere constructive dialogue between biblical, ecclesial and ndrŭnaphone cultures. The same and unique God had revealed herself or himself to the Indrǔ (Ngiti) people as
Kàgàwà and allowed them at the appointed time to recognise and confess Jesus as His Son. Another vital element for the Christian faith confession is the Church mediation. Without a Church mediation, the Christian and salvific confession of Jesus as Son of God in Ndrǔna language ('Yěsù [Yěsùwa] ní Kàgàwà t'Ídhùnà') will neither be possible or intelligible, nor will it be conceivable without the Ndrǔna religious system.

In Africa, intercultural hermeneutics applied to New Testament texts with consequent literary analyses originates from Justin Ukpong. The latter claims to have coined the phrase 'inculturation biblical hermeneutics' whilst studying the parable of the wise steward (Lk 16:1-13). He sees this approach as an application of the paradigm of inculturation to biblical interpretation. He combines popular African readings with historical-critical methods to interpret the biblical texts (Ukpong 1996:192). Thus, the ordinary readers are positioned as subjects of interpretation and not simply fields of application (Ukpong 1995, 2001, 2002a, 2002b, 2003, 2012; see also Tshehla 2015). However, the ordinary readers remain mere informants for the professional exegetes. Yet, they are ordinary exegetes who form part of 'sensus fidelium' (meaning by the faithful) and whose views complement those of the scholars. The Catechism of the Catholic Church (\# 92) defines the sensus fidelium as:

[T] he supernatural appreciation of faith on the part of the whole people, when from the bishops to the last of the faithful, they manifest a universal consent in matters of faith and morals.

Two years following Ukpong (1996), Jean-Bosco Matand uses the same method without being aware of the previous similar publication. He interprets the story of the Council of Jerusalem (Ac 15:1-35 and Gl 2:11-14), by using the hermeneutics of inculturation that integrates historicalcritical and literary analyses (Matand 1998). However, he uses the target context as a field of application for the results of historical-critical exegesis. Matand's intercultural approach follows mainly three stages: contextualisation, decontextualisation and recontextualisation. ${ }^{3}$ This approach risks stripping the interlocutors of the target context of their rights of being interpretive subjects to become fields of application.

Marie-Paul Buetubela-Balembo prefers the expression 'biblical approach to inculturation' and applies it to the evangelical tradition of which the sayings and deeds of Jesus constitute the central object. In the relationship between the gospel and culture, Buetubela-Balembo (1998:140) sees in 'Jesus Christ himself the main subject or author of inculturation, for he is the Word proclaimed by the evangelizer and the Word welcomed by the culture of the believer'. Furthermore, he considers translation as an intercultural process. He emphasises the transcendent character of the gospel concerning both the culture of origin and the target culture (Buetubela-Balembo 1998:141). Buetubela and Matand apply the results of literary analyses to target contexts without having listened to them beforehand.

3.See Matand (1998:143-167, 2002:73-84, 2005:35-49, 2010a:110-122, 2010 b: 171-187). 
A new terminology emerged with Antoine Ndayango Cilumba Cimbumba in his study of the dialogue between Jesus and Nicodemus (Jn 2:23-3:36). He uses the term 'intercultural hermeneutics' or 'intercultural exegeses' and considers them synonymous and interchangeable with biblical hermeneutics of inculturation. In addition, Ndayango borrows epistemological foundations of intercultural hermeneutics from Hans-Georg Gadamer and Paul Ricoeur regarding pre-comprehension, fusion of horizons and appropriation of the text. For the two philosophers and Ndayango, 'the interpreter or the reader constitutes a pillar for understanding an event' (Ndayango 2001:12, 2003:45-62). Nonetheless, Ndayango's intercultural exegesis combines the study of literary structure and the traditional and redactional criticisms of John 2:23-3:36 before applying the results to the Congolese context, which then becomes a field of application for his exegesis.

Chris Ukachukwu Manus (2003a; see also 2003b) applies intercultural methods and procedures to several New Testament texts by combining historical, literary and social methods in a single book. He distinguishes between intercultural folkloric approach and intercultural hermeneutics. The procedures of intercultural folkloric approach include: establishing the text and its original context of the biblical text, analysing this text, presenting characters in it, showing conflicting data in text and identifying the symbolism present in the text and their equivalents in the target culture. The procedures of intercultural hermeneutics involve the following: choosing a biblical text, a brief presentation of the problem, justification of intercultural hermeneutics, analysis of the context of the current performer, analysis of the socio-historical context of the biblical story, exegetical analysis of text, interpretation of the text, contextualisation, conclusion, notes and references.

The author of this study has devoted several studies to intercultural hermeneutics. He refers to the same method with different synonyms such as intercultural exegesis, intercultural mediation, intercultural construction, intercultural criticism, intercultural narrative criticism or intercultural ecojustice hermeneutics. He has so far applied it in three areas that are distinct but interconnected: biblical exegesis (the New Testament), ${ }^{4}$ translation criticism ${ }^{5}$ and canonical criticism. ${ }^{6}$

For intercultural biblical exegesis and intercultural canonical criticism, the author has used historical, literary, social, narrative and ecojustice hermeneutics, whilst his intercultural translation study essentially incorporates the theory of functional equivalence (Nida 1982; Nida \& Taber 1969; cf. Loba-Mkole 2019b). He defines intercultural construction as a combination of inculturation and construction perspectives

4.Cf. Loba-Mkole (2000a:1119-1145, 2000b:557-566, 2002:61-77, $2006: 51-70$ 2007a:39-68, 2007b:141-59, 2008:20-36, 2010:115-132, 2011:1-11, 2012 2013:1-8, 2014a:112-134, 2014b, 2019a:1-8, 2020a:89-116, 2020b:281-305).

5.Cf. Loba-Mkole (2004:37-58, 2008b, 2009a:76-115, 2009b:25-43, 2011:74-84, 2013a:96-119, 2013b:508-522, 2020b, 2020c: forthcoming).

6.Cf. Loba-Mkole (2016:240-261, 2019b:156-180); see Manus (2003b:659-669).
(Loba-Mkole 2016:254), involving three frames of reference (a contemporary culture, a past church culture and an original biblical culture):

1. The contemporary culture includes a self-presentation of the interpreter and a literature review highlighting mainstream and alternative interpretations.

2. The church culture frame displays the mainstream interpretations of a chosen church and alternative interpretations from other churches.

3. The reference frame of the original biblical culture undertakes a literary analysis of a selected main text and that of a parallel text, by using their original languages.

The conclusion of an intercultural construction may summarise the points of similarity and dissimilarity between an original biblical culture, an ecclesial culture and a contemporary culture, as well as providing a way forward for the target culture, indicating the epistemological and ethical values of suggestions made (cf. Loba-Mkole 2013a, 2016, 2019a, 2020a).

Elizabeth Mburu (2019) offers a four-legged stool model of an intercultural biblical hermeneutics in Africa and applies it to the Old Testament and New Testament texts. The four legs feature the parallels to African contexts, theological context, literary context and historical and cultural contexts, whilst the stool's seat corresponds to the application (Mburu 2019:65-89). Thus, the four legs may represent two components: the African contexts and the biblical texts understood in their theological, literary, historical and cultural contexts.

Elie Sikamosi-Nzoloko (2019) uses an intercultural exegesis that combines narrative analysis and translation criticism of the Gospel of John (4:1-42). His intercultural model includes mainly an original biblical culture (Johannine narrative of the Samaritan Woman) and Lingala Bible Translations, including the New Lingala Bible Translation (Sikamosi-Nzoloko 2019:14-22).

In summary, the history and procedures of the method of intercultural constructions in Africa are palpable. This method started with the immemorial period that witnessed the communication between God and ancestors, as recorded in religious discourses. The latter may account even for a confession of Christian faith like the one in Ndrŭna (Ngiti) language: Yěsù (Yěsùwa) ní Kàgàwà t'Ídhùnà' (literally Jesus [Yeshuah] is the Son of יהוה, cf. Mk 1:1; 14:62). Ukpong and Matand have each independently formulated and applied inculturation hermeneutics as a method of analysis and interpretation of biblical texts, especially those of the New Testament. However, Ndayango calls this method intercultural exegesis and presents its epistemological foundations in the line of Gadamer and Ricoeur. This intercultural exegesis integrates literary structure, tradition and redaction criticisms. Buetubela Balembo's contribution has made a clear distinction between the gospel and the culture, including the translation as part of the biblical inculturation hermeneutics. He proceeds 
in three stages: the analysis of the vocabulary of the chosen text, its interpretation and its application to a context (cf. Batuafe-Ngole 2020; Kabasele-Mukenge 2010; LeMarquand 2000:680-681). Manus's contribution has made intercultural biblical hermeneutics a unifying paradigm of different stages encompassing several historical-critical, literary and folkloric interpretive methods.

Moreover, Manus includes other paradigms such as liberation, (re) construction and even post-colonialism in intercultural exegesis. My contribution consists of a threedimensional intercultural dialogue (original biblical cultures, ecclesial cultures and contemporary cultures), applied to a three-fold domain (biblical exegesis, translation and canon). Mburu's intercultural method integrates four stages: African contexts, theological context, literary context and historical and cultural contexts, followed by application. SikamosiNzoloko's intercultural model involves narrative criticism and translation criticism.

\section{Epistemological foundations of intercultural construction}

An epistemological task refers to the intellectual and practical efforts that must lead to knowledge production (Aarde 1994:584). For the present model of intercultural construction, the rays of knowledge horizon assemble at the intersection of original biblical cultures, ecclesial cultures and contemporary target cultures. However, the journey of truth discovery must continue from that intersection of knowledge empowerment on the road that leads to the future, where resides the totality of the truth that illuminates the past, the present and the future itself. The epistemological foundations of my intercultural model include the following: interculturality as the cradle of the New Testament corpus, an existential mode, an interpretive paradigm and interaction with a triple hexagonal dimension of the truth.

\section{Interculturality as the cradle of the New Testament corpus}

The corpus of the New Testament is a product of intercultural interactions. It is a set of texts constructed (translated) from the Semitic languages or realities in the Greek language. In addition, these texts represent a reconstitution from different manuscripts or witnesses against the background of Jewish, Greek, Roman or other cultures (Betz 2001:5-8; Ehrensperger 2015:5-7).

The kerygma of the crucified and risen Christ that the New Testament or Biblical authors announce in their ways targets the Jewish cultures and others. One gospel has preserved eloquent testimony to this in connection with the motif of the crucifixion of Jesus, which has been worded in three languages, including Hebrew, Latin and Greek (see Jn 19:19-20).

The author of John 11:19-20 suggests that the addressees form an intercultural entity made up of people who can read a text in Hebrew, Greek or Latin. Indeed, he claims that many of the Jews read this motif of condemnation because of the closeness of the place of crucifixion of Jesus to the city and because of a trilingual labelling. This fact indicates that the Jewish people of Jesus' time had at least a triple intercultural framework which, moreover, is explained by the migratory movements of this people and those of its neighbours, suggesting a wider target audience (Keener 2013:1137). In some places, John portrays the Jews by using both positive and negative language. In social science terms, this description would serve to establish 'clear boundaries that create identity and solidarity within the community of believers' (Ehrensperger 2015:1; Holladay 2017:321). If Hebrew-, Greek- and Latin-speaking Christians were part of the community of believers to which the Gospel of John is addressed, this community would certainly be of intercultural obedience or one interested in inter-ecclesial dialogue (Standaert 2020:8).

The episode from Acts 2:7-11 emphatically portrays an intercultural context in which the Church was born on the day of Pentecost. Jews in the Diaspora or others could decipher in their languages what the Galilean disciples say in their dialect. These people would represent 12 geographic regions: Persia, Babylonia, Cappadocia, Armenia, Asia, Greece and Ionia, Libya and Cyrene, Italy, Cilicia and Crete, Egypt and finally the Red Sea and India. They were probably associated with the following 12 astrological signs: Aries, Taurus, Gemini, Cancer, Leo, Virgo, Libra, Scorpio, Sagittarius, Capricorn, Aquarius and Pisces (Holladay 2016:97-98). Symbolically, the 12 apostles might have been addressing all the cultures of the world, represented by 12 geographic regions of that time.

The intercultural character of the New Testament or Biblical texts is thus constitutive of these texts as texts translated or produced by and for intercultural communities.

\section{Interculturality as an existential mode}

Interculturality is an existential mode, a way of being, thinking and acting. Philosophical anthropology generally regards the human person as a being of lacks and desires. Wolfhart Pannenberg asserts that this intuition attributed to Johan Gottfried Herder has never been exceeded (Herder 1967:107108; Pannenberg 1985:43). Because of these gaps, voids, lacks, needs or desires, the human being immediately appears foreign to himself or herself (Nietzsche 1887:209). However, this does not inevitably reduce the human person to a completely static being. Instead, it is a springboard that allows human persons to project themselves into the future, choose themselves or collaborate responsibly in their future as relational beings. Karl Jaspers speaks of total existential communication or communication without frontiers (Jaspers 1948, 1949:38). However, the extent of human freedom and truth is measured by that of the others. 'I can only be free to the extent that the others are free' (Jaspers 1949:196). According to Senghor (1967), Negro-African thought views the human person and what surrounds him or her as complementary beings or forces: 
[F]or the Negro-African, everything or any force, is itself a knot of more elementary forces, the personal realization of which can only come from balance, from the harmony of its elements, and from their dialogue. This involves an inner or intra-personal dialogue between oneself and oneself, a male element and the female element, as well as an inter-personal dialogue, between complementary beings. (p. 7)

More recently, the studies by Bernhard Waldenfels ${ }^{7}$ reinforce the meaning of intercultural hermeneutics as a discourse that considers human reality as an interlace. He denounces monoculturalism, multiculturalism and transculturality. Monoculturalism recognises a single centre of culture, whilst multiculturalism replaces the idea of a single centre with that of a diversity of cultural centres. Transculturality claims to offer a third way by pretending to be universal in obedience whilst positioning itself as a space of cultural neutrality and indifference. Christian Ndala-Kabemba (2013) sums up Waldenfels'sthinking concerning thepitfalls ofmonoculturalism, multiculturalism and transculturality quite clearly:

$[T]$ o proceed in this way would mean not taking interculturality at its word and losing sight of the fact that the in-between expressed by the prefix 'inter' is not only the starting point of the experience of the foreigner, but also its environment. In other words, there is at the beginning neither (ethnocentric) unity nor multiplicity, but rather a difference-relation or a person as an interweaving of some cultures. (p. 64)

Thus, the human person as a human person is an intercultural entity tending towards its future in its communicative being, thought and action: 'the intercultural dimension is inherent to any cultural identity' (Santedi-Kinkupu 2013:132-143). Therefore, the mode of knowledge and interpretation that human persons exhibit results from the intercultural order inscribed in their philosophical-anthropological identity.

\section{Interculturality as an interpretative paradigm and method}

According to Segovia, cultural or intercultural criticism is a new paradigm that adopts a threefold strategy to interpret a religious text, canonical or non-canonical, from a liberationist and a postcolonial perspective (Segovia 1995b:321-329). For several African biblical exegetes, the intercultural method expands the inculturation paradigm or that of the inculturation paradigm coupled with other paradigms such as reconstruction and others (cf. Manus 2003a, 2003b).

\section{Interculturality as an interaction with a triple hexagonal dimension}

The intercultural construction envisaged here has six essential elements in each of three sets that condition the knowledge it generates. Firstly, it wants to avoid a triple pitfall, namely the cultural juxtaposition, cultural assimilation and cultural resignation (see Ndayango 2001, 2003:46-47; Tshiamalenga-Ntumba 1977:183-184). Then, it operates within a triple frame of reference, a triple epistemological privilege, a triple epistemological value, a triple ethical value and a triple cultural position. The triple frame of reference 7.Cf. Waldenfels (1971, 1997, 1998, 1999a, 1999b, 2006). includes original biblical cultures, past ecclesial cultures and contemporary target cultures. The triple epistemological privilege pertains to the unique epistemological privilege of canonicity granted to the original biblical cultures, the unique privilege of seniority conferred on ecclesial cultures and the unique epistemological privilege of liveliness bestowed upon contemporary cultures (contra Tamez 2002a:10, 2002b:58; Ukpong 2002a:17-32). The triple epistemological value concerns the consonance of an interpretation with the worldview of the target culture, with a historical message of Jesus and with past church culture. The triple ethical value evaluates a biblical interpretation in terms of its correctness vis-à-vis the original biblical culture, loyalty towards the target culture and sincerity towards the ecclesial culture of the interpreter. Finally, the triple cultural scope features the current cultural position, horizontal cultures and vertical cultures of the interpreter (cf. Jonker 2006:19-28).

\section{Conclusion}

Proceeding by a descriptive approach, the present study has highlighted the history, procedures and epistemological foundations of intercultural constructions. The intercultural method operates in concert with other interpretive tools such as religious discourses, historical, literary, social or cultural methods. It also uses the procedures of chosen selected methods. The study has proposed the following epistemological foundations of intercultural method: interculturality as the cradle of the New Testament corpus, an existential mode, an interpretive paradigm and an interaction with a triple hexagonal dimension. The latter includes a triple pitfall (to avoid), a triple frame of reference, a triple epistemological privilege, a triple epistemological value, a triple ethical value and a triple cultural position.

\section{Acknowledgements Competing interests}

The author declares that he has no financial or personal relationships that may have inappropriately influenced him in writing this article.

\section{Author's contributions}

J.-C.L.-M. is the sole author of this article.

\section{Ethical considerations}

This article followed all ethical standards for research without direct contact with human or animal subjects.

\section{Funding information}

This research received no specific grant from any funding agency in the public, commercial or not-for-profit sectors.

\section{Data availability}

Data sharing is not applicable to this article as no new data were created or analysed in this study. 


\section{Disclaimer}

The views and opinions expressed in this article are those of the author and do not necessarily reflect the official policy or position of any affiliated agency of the author.

\section{References}

Aarde, A., 1994, 'The epistemic status of the New Testament and the emancipatory living of the historical Jesus in engaged hermeneutics', Neotestamentica 28(2), 575-596.

Bassnett, S., 1998a, 'Translating across cultures', in S. Hunston (ed.), Language at work, pp. 72-85, Multilingual Matters, Clevedon.

Bassnett, S., 1998b, 'Translating the seed: Poetry and translation', in S. Bassnett \& A. Lefevere (ed.), Constructing cultures. Essay on literary translation, pp. 57-75, Multilingual Matters, Clevedon.

Bassnett, S. \& Lefevere, A. (eds.), 1990, Translation, history and culture, Pinter, London.

Bassnett, S. \& Lefevere, A. (eds.), 1998, Constructing cultures, Multilingual Matters, Clevedon.

Batuafe-Ngole, F., 2020, 'Tribalité et religion en Afrique et dans la Bible: Approche interculturelle', Cahier des Religions Africaines 1(1), 111-124.

Betancourt-Fornet, R., 2011, La philosophie interculturelle penser autrement le monde, Atelier, Montréal.

Bimwenyi, O.K., 1981, Discours théologique négro-africain: Problème de fondements, Présence africaine, Paris.

Bimwenyi, O.K., 1998, 'L'expérience religieuse négro-africaine traditionnelle', in J. Kalonga (ed.), Inculturation de la vie consacrée en Afrique à l'aube du troisième millénaire: Actes du cinquième colloque international, pp. 33-44, Carmel Afrique, Kinshasa.

Betz, D.H., 2001, 'Remarks of the SNTS president', in M.N. Getui, T. Maluleke \& J. Ukpong (eds.), Interpreting the New Testament in Africa, pp. 5-8, Acton Publishers, Nairobi.

Bleich, D., 1975, Readings and feelings: An introduction to subjective criticism National Council of Teachers of English, Urbana.

Brown, D., Davaney, G.S. \& Tanner, K. (eds.), 2001, Converging on culture: Theologians in dialogue with cultural analysis and criticism, Oxford University Press, New York, NY.

Buetubela-Balembo, M.-P., 1998, 'Approche biblique de l'inculturation dans la tradition évangélique', in J. Kalonga (ed.), Inculturation de la vie consacrée en Afrique à l'aube du troisième millénaire: Actes du cinquième colloque international, pp. 135-141, Carmel Afrique, Kinshasa.

Bujo, B. \& Ilunga, J.M. (eds.), 2003-2013, African theology: Contributions of the pioneers, 3 Vols, Paulines Publications Africa, Nairobi.

Deist, F., 2000, Material culture of the bible: An introduction, Sheffield Academic Press, Sheffield.

De Wit, H., 2004a, 'Intercultural hermeneutics', in H. De Wit, L. Jonker, M. Kool \& D. Schipani (eds.), Through the eyes of another: Intercultural reading of the bible, D. Schipani (eds.), Through the eyes of another: Intercultural
pp. 477-492, Institute of Mennonite Studies, Amsterdam.

De Wit, H., 2004b, 'Through the eyes of another: Objectives and backgrounds', in $\mathrm{H}$. De Wit, L. Jonker, M. Kool \& D. Schipani (eds.), Through the eyes of another: Intercultural reading of the bible, pp. 3-53, Institute of Mennonite Studies, Amsterdam.

De Wit, H., 2012, Empirical hermeneutics, interculturality, and holy scripture, Institute of Mennonite Studies, Elkhart.

Dunn, D.G.J., 2003, Jesus remembered, Eerdmans, Grand Rapids, MI.

Easthope, A., 1991, Literary into cultural Studies, Routledge, New York, NY.

Ehrensperger, K., 2015, Paul at the crossroads of cultures: Theologizing in the space between, Bloomsbury T \& T Clark, London.

Exum, J.C. \& Moore, D.S. (eds.), 1998, Biblical studies/cultural studies: The third Sheffield Colloquium, Sheffield Academic Press, Sheffield.

Faiq, S., 2004, 'The discourse of intercultural translation', Intercultural Communication Studies 13(3), 35-46.

Grossberg, L., Nelson, C. \& Treichler, P. (eds.), 1993, Cultural studies, Routledge, New York, NY.

Hall, S., 1980, 'Cultural studies: Two paradigms', Media, Culture, and Society 2(1), 57-72. https://doi.org/10.1177/016344378000200106

Han, Y.S. \& Beyers, J., 2017, 'A critical evaluation of the understanding of God in J.S Mbiti's Theology', Acta Theologica 37(2), 5-29.

Herder, G.J., 1967, Essay on the origin of language, transl. J.H. Moran \& A. Gode, Bergman, New York, NY.

Hoggart, R., 1957, The uses of literacy. Aspects of working-class life with special reference to publication and entertainments, Chatto and Windus, London.

Holland, N., 1968, The dynamics of literary response, Oxford University Press, Oxford.

Holladay, R.C., 2016, Acts: A commentary, Westminster John Knox Press, Louisville, KY.

Holladay, R.C., 2017, Introduction to the New Testament, Reference edition, Baylor University Press, Waco, TX.

Iser, W., 1974, The implied reader: Patterns of communication in prose fiction from Bunyan to Beckett, John Hopkins University, Baltimore, MD.
Iser, W., 1975, The implied reader, Johns Hopkins University Press, Baltimore, MD.

Iser, W., 1978, The act of reading: A theory of aesthetic response, John Hopkins University Press, Baltimore, MD.

Jaspers, K., 1948, Der philosophische Glaube, Piper, München.

Jaspers, K., 1949, Vom Ursprung und Ziel der Geschichte, Piper, München.

Jonker, L., 2006, 'From multiculturality to interculturality: Can intercultural biblical hermeneutics be of any ssistance', Scriptura 1, 19-28.

Kabasele-Lumbala, F., 1993, Le Christianisme et l'Afrique: Une chance réciproque, Karthala, Paris.

Kabasele-Mukenge, A., 2010, Bible et promotion humaine. Mélanges en l'honneur du Professeur P.-M. Buetubela Balembo, Université Catholique du Congo, Kinshasa.

Keener, C.S., 2013, Acts: An exegetical commmentary, Vol. 1. Introduction and 1:1-2:47, Baker Academy, Grand Rapids, MI.

Klingbeil, A.G., 2005, 'Cultural criticism and biblical hermeneutics: Definition, origins, benefits and challenges', Bulletin for Biblical Research 15(2), 261-277.

Kutsch, C.L., 1993, Ngiti: A central-Sudanic language of Zaire, Rüdiger Köppe, Köln.

LeMarquand, G., 2000, 'A bibliography of the bible in Africa', in G.O. West \& M.W. Dube (eds.), The bible in Africa: Transactions, trajectories and trends, pp. 633-800, Brill, Leiden.

Loba-Mkole, J.-C., 2000a, 'Mk 14.62: Substantial compendium of New Testament Christology', HTS Teologiese Studies/Theological Studies 56(4), 1119-1145. https://doi.org/10.4102/hts.v56i4.1810

Loba-Mkole, J.-C., 2000b, 'The Kiswahili mwana wa mtu and the Greek ho huios tou anthrôpou', in G. West \& M.W. Dube (eds.), The bible in Africa: Transactions, trajectories, and trend, pp. 557-566, Brill, Leiden.

Loba-Mkole, J.-C., 2002, 'Video scriptures as prophecy and exegesis', in K.L. Santedi \& A. Kabasele (eds.), Une théologie prophétique pour l'Afrique, pp. 61-77, Facultés Catholiques de Kinshasa, Kinshasa.

Loba-Mkole, J.-C., 2004, 'Bible translation and inculturation hermeneutics', in E.R. Wendland \& J.C. Loba-Mkole (eds.), Biblical texts and African audiences, pp. 37-58, Acton, Nairobi.

Loba-Mkole, J.-C., 2005a, 'Social setting of Jesus' exaltation in Luke-Acts (Lk 22:69, Ac 7:56)', HTS Teologiese Studies/Theological Studies 61(1/2), 291-326. https://doi. org/10.4102/hts.v61i1/2.441

Loba-Mkole, J.-C., 2005b 'Exégèse contextuelle africaine: Evaluation à partir d'un livre récent', Revue Africaine de Théologie 58, 243-265.

Loba-Mkole, J.-C., 2006, 'Ethics of a business manager: Intercultural exegesis of Luke 16:1-18', Hekima Review 36, 51-70.

Loba-Mkole, J.-C., 2007a, 'From inculturation theology to intercultural exegesis', in A. Kabasele-Mukenge, J.-C. Loba-Mkole \& D. Aroga-Bessong (eds.), Cultural readings of the bible in Africa, pp. 39-68, Clé, Yaoundé.

Loba-Mkole, J.-C., 2007b, 'Autorité et sagesse du fils d'homme en Mc 2,10.28. Approche interculturelle', in J.-B. Matand (ed.), Sagesse humaine et sagesse divine dans la Bible: Lectures bibliques dans le contexte de l'Eglise Famille de Dieu en Afrique. Actes du 12ème Congrès de l'APECA, pp. 141-159, Association Panafricaine des Exégètes Catholiques, Kinshasa.

Loba-Mkole, J.-C., 2008a, 'Be reconciled to God (2 Cor 5:20d): Demoting violence and promoting peace', Hekima Review 39, 20-36.

Loba-Mkole, J.-C., 2008b, 'History and theory of bible translations', HTS Teologiese Studies/Theological Studies 64(1), 253-266. https://doi.org/10.4102/hts.v64i1.20

Loba-Mkole, J.-C., 2009a, 'Bible translation and reconstruction hermeneutics', Acta Patristica et Byzantina 20(1), 28-44. https://doi.org/10.1080/10226486.2009.118 79095

Loba-Mkole, J.-C., 2009b, 'Exegesis and translation of Mark for audio-visual culture', Journal for the Biblical Text Research 24, 76-115. https://doi.org/10.28977/ jbtr.2009.4.24s.76

Loba-Mkole, J.-C., 2010, 'The New Testament and intercultural exegesis in Africa', in P. Foster (ed.), New Testament studies, pp. 115-132, Sage, London.

Loba-Mkole, J.-C., 2011a, 'Let's translate the scripture from the best sources', The Bible Translator/Practical Papers 62(2), 74-84. https://doi.org/10.1177/ 026009351106200204

Loba-Mkole, J.-C., 2011b, 'Paul and Africa?', HTS Teologiese Studies/Theological Studies 67(1), 1-11. https://doi.org/10.4102/hts.v67i1.888

Loba-Mkole, J.-C., 2012, Triple heritage: Gospels in intercultural mediations, 2nd edn., WordAlive, Nairobi.

Loba-Mkole, J.-C., 2013a, 'Ethics of prayer and work in 1 and 2 Thessalonians', HTS Teologiese Studies/Theological Studies 69(1), 1-8. https://doi.org/10.4102/hts. v69i1.2056

Loba-Mkole, J.-C., 2013b, 'An intercultural criticism of New Testament translations', Translation 3(4), 96-119.

Loba-Mkole, J.-C., 2014a, Le fils de l'homme néotestamentaire: Etude interculturelle, Editions Universitaires Européennes, Saarbrücken.

Loba-Mkole, J.-C., 2014b, 'Beyond just wages: An intercultural analysis of Mt. 20:1-16, Journal of Early Christian History 4(1), 112-134.

Loba-Mkole, J.-C., 2016, 'Intercultural construction of New Testament canons', in J.-C. Loba Mkole (ed.), Biblical canons in church traditions and translations, pp. 240-241, Sage, London.

Loba-Mkole, J.-C., 2019a, 'Interculturality in peace building (Rm 14:19)', HTS Teologiese Studies/Theological Studies 75(4), a5259. https://doi.org/10.4102/hts.v75i4.5259 
Loba-Mkole, J.-C., 2019b, 'Intercultural translations of Christian canonical scriptures', Acta Theologica 39(1), 156-180. https://doi.org/10.18820/23099089/actat.v39i1.9

Loba-Mkole, J.-C., 2020a, 'Peace and salt: Intercultural ecojustice hermeneutics of Mk 9:50', in J.-C. Loba-Mkole \& J.N.K. Mugambi (eds.), Peacebuilding in Africa: Biblical insights, pp. 89-116, Acton Publishers, Nairobi.

Loba-Mkole, J.-C., 2020b, 'Passion narrative as oral performance in Kiswahili (Mk 14:1-16:20)', in A.N. Mundele, E. Wabanhu \& J.-C. Loba-Mkole (eds.), Bible and orality in Africa: Interdisciplinary approaches, pp. 281-305, Catholic Biblical Centre for Africa and Madagascar - Centre Biblique Catholique pour l'Afrique et Madagascar, Nairobi.

Loba-Mkole, J.-C., 2020c, 'Intercultural frames of bible translation ownership', The Bible Translator Forthcoming.

Luka, L.N., 2008, De l'origine Kamite des Civilisations Africaines: Lecture afrocentrique de quelques récits, Menaibuc, Paris.

Luka, L.N., 2010, Jésus-Christ et la religion africaine: Réflexion christologique à partir de l'analyse des mythes d'Osiris, de Gune, d'Obatala, de Kiranga et de Nzala Mpanda, Gregorian and Biblical Press, Roma.

Luz, U., 2007, Mathew 1-7, Fortress Press. Minneapolis, MN.

Mabee, C., 1991, Reading sacred texts through American eyes: Biblical interpretation as cultural critique, Mercer University Press, Macon, GA.

Manus, U.C., 2003a, Intercultural hermeneutics in Africa: Methods and approaches, Acton, Nairobi.

Manus, U.C., 2003b, 'Scriptures and canon: Interpretations of the bible in contemporary African Christianity', in J.-M. Auwers \& H.J. De Jonge (eds.), The biblical canons, pp. 659-669. Leuven University Press, Leuven.

Matand, J.-B., 1998, 'L'herméneutique de l'inculturation dans Ac 15 et Ga 2,11-14', in J. Kalonga (dir.), Inculturation dans la vie consacrée en Afrique à l'aube du J. Kalonga (dir.), Inculturation dans la vie consacrée en Afrique à l'aube du
troisième millénaire. Actes du cinquième colloque international, pp. 143-167, troisième millénaire. Actes

Matand, J.-B., 2002, 'L'itinéraire d'un exégète vers le savoir', Revue Africaine de Théologie 51, 73-84.

Matand, J.-B., 2005, 'From text to meaning: The Itinerary of an exegete and the task of inculturation', African Christian Studies 21(3), 35-49.

Matand, J.-B., 2010a, 'The world in front of the text and the use of the bible as Norma Normans in ethics', in P.C. Chummar (ed.), Natural Law ... In search of a common denominator... proceedings of the 1st International symposium, pp. 110-122, Catholic University of Eastern Africa, Nairobi.

Matand, J.-B., 2010b, 'Je suis le chemin, la vérité et la vie. Lecture exégétique de Jn 14 6 dans une perspective africaine', in A. Kabasele-Mukenge (ed.), Bible et promotion humaine. Mélanges en l'honneur du Professeur P.-M. Buetubela Balembo, pp. 171-187, Université Catholique du Congo, Kinshasa.

Mburu, E., 2019, African hermeneutics, HippoBooks Langham Publishing, Carlisle.

Moore, S.D., 1992, 'Introduction: The lives of mark', in J.C. Anderson \& S.D. Moore (eds.), Mark and methods: New approaches in biblical studies, Fortress Press, Minneapolis, MN.

Moxnes, H., 1998, 'The historical Jesus: From master narrative to cultural context', Bulletin for Biblical Research 28(4), 135-149. https://doi.org/10.1177/ 014610799902800403

Ndala-Kabemba, C., 2013, 'Réflexion Philosophique sur le concept de l'interculturalité', in L. Santedi-Kinkupu (ed.), Unité et pluralité en Théologie. Mélanges offerts au Professeur Alphonse Ngindu Mushete, pp. 54-74, Université Catholique du Congo, Kinshasa.

Ndayango, C.C.A., 2001, Wunder, Glaube und Leben bei Johannes: Eine exegetischhermeneutische Studie am Beispiel von Joh 3 im Hinblick auf die Inkulturationsaufgabe, Borengässer, Bonn.

Ndayango, C.C.A., 2003, 'La contribution de l'exégèse à la tâche de l'inculturation', Revue Africaine de Théologie 53, 45-62.

Ngalula-Tshianda, J., 2020, 'Les dynamismes porteurs de l'expression religions (traditionnelles) africaines', Cahier des Religions Africaines 1(1), 9-38.

Ngindu-Mushete, A., 1989, Les thèmes majeurs de la théologie africaine, L'Harmattan, Paris.

Nida, A.E., 1982, 'Establishing translation principles and procedures', The Bible Translator/ Practical Papers 33, 202-213. https://doi.org/10.1177/026009438203300202

Nida, A.E. \& Taber, R.C., 1969, Theory and practice of translation, Brill, Leiden.

Nietzsche, F., 1887, Zur Genealogie der Moral, Von Michael Holzinger Erstdruck, Leipzig.

Obenga, T., 1993, Origine commune de l'égyptien ancien du copte et des langues négro-africaines modernes: Introduction à la linguistique historique africaine L'Harmattan, Paris.

Pannenberg, W., 1985, Anthropology in theological perspective, T\&T Clark, Edinburgh.

Pénoukou, E.J., 1991, 'The churches of Africa: Their identity? Their mission?', in W. Jenkinson \& H. O'Sullivan (eds.), Trends in mission toward the 3rd millennium pp. 39-45, Orbis Books, Maryknoll, NY.

Santedi-Kinkupu, L., 2013, 'La pratique de la théologie dans le contexte de l'interculturalité. Défis et perspectives', in L. Santedi-Kinkupu (ed.), Unite et pluralité en Théologie. Mélanges offerts au Professeur Alphonse Ngindu Mushete, pp. 132-143, Université Catholique du Congo, Kinshasa.
Schnelle, U., 2005, Apostle Paul: His life and theology, Baker Academy, Grand Rapids, MI.

Segovia, F.F., 1995a, 'Towards a hermeneutics of the diaspora: A hermeneutic of otherness and engagement', in F.F. Segovia \& M.A. Tolbert (eds.), Reading from this place, Vol. 1, Social location and biblical interpretation in the United States, pp. 57-73, Fortress Press, Minneapolis, MN.

Segovia, F.F., 1995b, 'Towards intercultural criticism: A reading strategy from the diaspora', in F.F. Segovia \& M.A. Tolbert (eds.), Reading from this place, Vol. 2, Social location and biblical interpretation in global perspective, pp. 303-330, Fortress, Minneapolis, MN

Senghor, S.L., 1967, Les Fondements de l'africanité: Ou, Négritude et arabité, Présence africaine, Paris.

Shanor, J., 1988, 'Paul as master builder: Construction terms in first Corinthians', New Testament Studies 34(3), 461-471. https://doi.org/10.1017/S002868850002021X

Sikamosi-Nzoloko, E., 2019, Jésus et la femme samaritaine: Lecture narrative et traduction en lingala de Jn 4,1-42, Université Catholique du Congo, Kinshasa.

Sparks, C., 1997, 'The evolution of cultural studies', in J. Storey (ed.), What is cultural studies: A reader, pp. 14-30, Arnold, London.

Standaert, B., 2020, Nouvelle approche du quatrième évangile. L'enjeu inter-ecclésial de son édition et les implications pour tout dialogue, Pontificio Ateneo S. Anselmo,

Storey, J. (ed.), 1996, What is cultural studies: A reader, Arnold, London.

Tamez, E., 2002a, 'Reading the bible under a sky without stars', in W. Dietrich \& U. Luz (eds.), The bible in a world context: An experiment in contextual hermeneutics, pp. 3-15, Eerdmans, Grand Rapids, MI.

Tamez, E., 2002b, 'A star illuminates the darkness', in W. Dietrich \& U. Luz (éds.), The bible in a world context: An experiment in contextual hermeneutics, pp. 53-59, Eerdmans, Grand Rapids, MI.

Tshehla, S.M., 2015, 'Justin Ukpong's Jesus Emmanuel for our times', Missionalia 43(3), 292-305. https://doi.org/10.7832/43-3-119

Tshiamalenga-Ntumba, M., 1977, 'Exégèse biblique et philosophie de langage', Revue Africaine de Théologie 1, 165-184.

Ukpong, J., 1995, 'Reading the bible with African eyes', Journal of Theology for Southern Africa 91, 3-14.

Ukpong, J., 1996, 'The parable of the Shrewd manager (Luke 16:1-13): An essay in inculturation hermeneutic', Semeia 73, 189-210.

Ukpong, J., 2001, 'The workers in the vineyard parable (Matt 20:1-16): A reading with a community of ordinary readers', in M. Getui, T. Maluleke \& J. Ukpong (eds.), New Testament hermeneutics in Africa, pp. 88-112, Acton, Nairobi.

Ukpong, J., 2002a, 'Inculturation Hermeneutics: An African approach to biblical interpretation', in W. Dietrich \& U. Luz (eds.), The bible in a world context:
An experiment in contextual hermeneutics, pp. 17-32, Eerdmans, Grand An experiments,
Rapids, MI.

Ukpong, J., 2002b, 'Reading the bible in the global village: Issues and challenges from African readings', in J. Ukpong, M.S Dube, G.O. West, A. Masoga, N.K. Gottwald, J.
Punt et al. (eds.), Reading the bible in the global village., pp. 9-39, Society of Punt et al. (eds.), Reading the
Biblical Literature, Atlanta, GA.

Ukpong, J., 2003, 'The good news according to Matthew', in D. Patte (eds.), The gospel of Matthew: A contextual introduction for group study, pp. 141-147, Abingdon, of Matthew: $A$.
Nashville, TN.

Ukpong, J., 2012, 'The parable of the talents (Matt 25:14-30): Commendation or critique of exploitation? A social-historical and theological reading', Neotestamentica 46(1), 190-207.

Waldenfels, B., 1971, Das Zwischenreich des Dialogs: Sozialphilosophische Untersuchungen in Anschlu $\beta$ an E. Husserl, M. Nijhoff, Den Haag.

Waldenfels, B., 1997, Topographie des Fremden, Suhrkamp (Studien zur Phänomenologie des Fremden 1), Frankfurt am Main

Waldenfels, B., 1998, Grenzen der Normalisierung, Suhrkamp, (Studien zur Phänomenologie des Fremden 2), Frankfurt am Main

Waldenfels, B., 1999a, Sinnesschwellen, Suhrkamp (Studien zur Phänomenologie des Fremden 3), Frankfurt am Main

Waldenfels, B., 1999b, Vielstimmigkeit der Rede, Suhrkamp (Studien zur Phänomenologie des Fremden 4), Frankfurt am Main.

Waldenfels, B., 2006, Grundmotive einer Phänomenologie des Fremden, Suhrkamp, Frankfurt am Main.

West, O.G., 1995, Biblical hermeneutics of liberation: Modes of reading the bible in the South African context, 2 nd edn., Cluster, Pietermaritzburg, Orbis, Maryknoll, NY.

West, O.G., 1999, The academy of the poor: Towards a dialogical reading of the bible, Sheffield Academic Press, Sheffield.

West, O.G., 2014, ‘Locating contextual bible study within biblical liberation hermeneutics and intercultural biblical hermeneutics', HTS Theological Studies 70(1), a2641. https://doi.org/10.4102/hts.v70i1.2641

Williams, R., 1958, Culture and society, Chatto and Windus, London.

Williams, R., 1961, Long revolution, Chatto and Windus, London.

Wimbush, L.V., 1989, 'Historical/cultural criticism as liberation: A proposal for an African American biblical hermeneutic', Semeia 47, 43-55. 